\title{
Application of liquid and water-soluble special fertilizers and biostimulators in agropedocenoses of the forest-steppe zone
}

\author{
$L$ Levshakov, $N$ Volobueva \\ Kursk State Agricultural Institute named after I.I. Ivanov, Kursk, Russian Federation
}

\begin{abstract}
The value of foliar dressing is presented to achieve the maximum productivity of cultivated crops in agropedocenoses of the forest-steppe zone of the Russian Federation. When cultivating apple orchards in perennial agropedocenoses according to intensive technologies, the optimization of the nutritional regime is one of the most significant factors in obtaining a stably high crop yield of high-quality fruits. To fully provide apple trees with nutrient elements and growth biostimulators during the growing season, it is necessary to use special fat and water-soluble fertilizers and growth biostimulators. Most effectively, they are applied along the leaf surface as a foliar dressing. The leaf surface systems we developed and tested include the introduction of macro-, meso- and microelements and biological stimulating agents. The latter include various groups and types of amino acids, root, growth and development, flowering and setting, ripening and staining stimulating agents. The use of an integrated foliar dressing system has made it possible to provide the most complete need for apple trees with the necessary nutrients and compounds during the entire growing season. The obtained experimental data showed a high efficiency in changing a balanced system of foliar dressing in an intensive apple orchard. Compared to the control, there was a significant increase in the growth activity of the central conductor and fruit wood. Fruit setting rates, caliber and weight of apples and therefore more than $95 \%$ of the yield corresponded to the highest and first grade. The yield increased significantly compared to the control, it was from 28 to $66 \%$ for varieties and variants. Experimental studies showed high efficiency of foliar dressing with special fertilizers and growth biostimulating agents.
\end{abstract}

\section{Introduction}

At present, the main objective of the gardening industry was to maximize the productivity and costeffectiveness of intensive gardens. Thus, it is necessary to improve the technological cultivation methods in order to increase the yield and quality of the obtained products $[1,2]$ Modern cultivation technologies for garden crops use a balanced feeding system as one of the main technological techniques for increasing productivity. According to many researchers [3, 4], the feeding system of an intensive apple orchard should annually begin early in spring and end in fall after harvest. Only in this case, when all other technological techniques are followed, it is possible get the maximum yield of high-quality fruits.

In the apple orchards of the forest-steppe of Chernozem Region cultivated using intensive technologies soil-climatic conditions allow obtaining yields of up to 60 tons/ha. In order to achieve this it is necessary to observe all technological techniques, starting from the choice of variety-water combinations, laying, care work, protection from harmful organisms, ensuring the full need for nutritional elements [5]. It is believed that the issues of compiling an integrated and balanced feeding system for the apple orchard, which would take into account the characteristics of the variety, specificity and fertility of soils, weather conditions are most relevant and require special attention of gardeners and agrochemists. Currently, the complex fertilization system of the apple orchard consists of three directions: 1 - introduction of feed products into the soil before planting and as foliar dressing, 2 - introduction of feed products with irrigated water, 3 - introduction of feed products on the leaf surface. The maximum efficiency of measures to optimize mineral nutrition is achieved only with a combination of fertigation and foliar dressing [6]. Fertigation in combination with foliar dressing affects organic matter content and fruit quality and provides great potential to manage yield and fruit quality at relatively low cost and high environmental friendliness of interventions [7]. In intensive apple orchards it is necessary to ensure a balanced nutrition of plants, including micronutrients in combination with biostimulators, which may best be done using foliar dressing [8]. Most often, they are combined in tank 
mixtures with the introduction of pesticides, which reduces production costs. The number of foliar dressing sometimes exceeds 20 times during the growing season, which requires a careful analysis of their agronomic and economic effectiveness. The use of foliar dressing provides a significant increase in the percentage of high-yield fruits [9].

Over the past 15 to 20 years, intensive horticulture technologies had undergone significant changes and were developing in several main areas. One of them is a complete and balanced feed system [6]. In order to obtain a yield of 35-60 tons/ha, it is necessary to introduce the full norm of feed elements with fertilizers. It is mandatory to introduce not only macro-
, but also meso- and microelements during vegetation periods, when apple trees mostly need them [10]. But the introduction of only feed elements in an intensive garden is already becoming insufficient. Therefore, in recent years, broad-spectrum stimulating agents, amino acids, and humic drugs have been increasingly included in the nutrition systems of garden crops. The use of biological stimulants will increase the size of the fruits, accelerate their maturation, and improve staining ability. This makes it possible to fully realize the potential of modern varieties of apple trees of domestic and foreign breeding designed for intensive horticulture, and get the maximum productivity.

Table 1. Variants for foliar dressing, 2019-2020

\begin{tabular}{|c|c|c|c|}
\hline$n / n$ & $\begin{array}{l}\text { Phase of } \\
\text { development }\end{array}$ & Ikar, Biolchim foliar dressing system & $\begin{array}{llll}\begin{array}{l}\text { Fitofert, Terra } \\
\text { dressing system }\end{array} & \text { Tarsa } & \text { foliar } \\
\end{array}$ \\
\hline 1 & Auricles & Ikar Zinto & - \\
\hline 2 & In 4 days & $\begin{array}{l}\text { Kafom Zn, Philloton, IkarEnzo } \\
\text { Aquasilk }\end{array}$ & Paverfol Phosphozinc, Fitofert Asset \\
\hline 3 & Pink bud & $\begin{array}{l}\text { Philloton, Boromin Gel, IkarFosto } \\
\text { Aquasilk }\end{array}$ & $\begin{array}{l}\text { Phytofert combivite, Monocalium } \\
\text { phosphate }\end{array}$ \\
\hline 4 & Initial blossom & $\begin{array}{l}\text { Philloton, Ikar NB-Mo, } \\
\text { Ikar Mendelenium, Aquasilk }\end{array}$ & - \\
\hline 5 & End of blossom & Locker, Ligoplex Ca, Aquasilk & - \\
\hline 6 & Petal fall & $\begin{array}{l}\text { Nutrivant universal, IkarRevolt, Ligoplex } \\
\mathrm{Ca} \text {, Atlante Plus, Ikar Mendelenium }\end{array}$ & Paverfall Kalmag, Fitofert Active \\
\hline 7 & In 7 days & $\begin{array}{llll}\text { Kafom } & \text { Mg, IkarEnzo, } & \text { Philloton, } \\
\text { Aquasilk }\end{array}$ & Speedfall Kalmag, Citodef \\
\hline 8 & Cobnut & Fosto Revolt & $\begin{array}{l}\text { Paverfol kalmag, Fitofert combivit, } \\
\text { Isabion }\end{array}$ \\
\hline 9 & Walnut & $\begin{array}{l}\text { Philloton, Ikar Mendelenium, Nutrivant } \\
\text { universal }\end{array}$ & $\begin{array}{lll}\text { Paverfol Phosphozinc, } & \text { Phytofert } \\
\text { Active, Phytofert Bioflex } & \\
\end{array}$ \\
\hline 10 & In 8 days & $\begin{array}{l}\text { Atlante+, Fruit Nutrivant, Ligoplex } \mathrm{Ca} \text {, } \\
\text { Aquasilk }\end{array}$ & - \\
\hline 11 & $\begin{array}{l}\text { Fruit growth, in } 15 \\
\text { days }\end{array}$ & $\begin{array}{l}\text { IkarEnzo, FostoRevolt, Fruit Nutrivant, } \\
\text { Ikar Mendelenium }\end{array}$ & $\begin{array}{l}\text { Paverfol kalmag, Fitofert mancin, } \\
\text { Citodef }\end{array}$ \\
\hline 12 & $\begin{array}{l}\text { Fruit growth, in } 10 \\
\text { days }\end{array}$ & Brassitrel, VigorResist, Atlante+ & - \\
\hline 13 & $\begin{array}{l}\text { Fruit growth, in } 7 \\
\text { days }\end{array}$ & Ligoplex Ca, Boromin Gel, Philloton & $\begin{array}{l}\text { Fitofert combivit, Paverfol boron, } \\
\text { Paverfol kalmag }\end{array}$ \\
\hline 14 & $\begin{array}{l}\text { Fruit filling, in } 7 \\
\text { days }\end{array}$ & Atlante + , Philloton, Fruit Nutrivant & - \\
\hline 15 & $\begin{array}{l}\text { Fruit filling, in } 7 \\
\text { days }\end{array}$ & $\begin{array}{lll}\begin{array}{l}\text { Kalisto, } \\
\text { phosphate }\end{array} & \text { Revolt, } & \text { mono-potassium } \\
\end{array}$ & - \\
\hline 16 & $\begin{array}{l}\text { Fruit filling, early } \\
\text { august }\end{array}$ & $\begin{array}{l}\text { Kalisto plus, Boromin Gel, Ligoplex } \mathrm{Ca} \text {, } \\
\text { Atlante+ }\end{array}$ & Fitofert Active, Speedfall kalmag \\
\hline 17 & $\begin{array}{lr}20 & \text { days before } \\
\text { harvesting }\end{array}$ & $\begin{array}{l}\text { Ligoplex Ca, Stimax, Fruit Nutrivant, } \\
\text { Boromin Gel }\end{array}$ & - \\
\hline 18 & $\begin{array}{l}10 \text { days before } \\
\text { harvesting }\end{array}$ & $\begin{array}{l}\text { Kalisto, Ikar Revolt, Резист, Ikar } \\
\text { Mendelenium, Atlante+ }\end{array}$ & Paverfol boron, Paverfol phosphocinc \\
\hline 19 & After harvesting & Ikar Revolt, Kalisto & Carbamide, $5-\%$ solution \\
\hline
\end{tabular}

\section{Materials and Methods}

The purpose of the study was to compile and practically test an integrated system of foliar dressing of the apple orchard based on high-tech liquid and water-soluble fertilizers and growth stimulating agents, which provide full and balanced nutrition taking into account varietal features, soil and climatic conditions, cultivation technology to achieve the maximum productivity.

Practical studies on the effectiveness of foliar dressing with special fertilizers and growth 
biostimulators were carried out in 2019-2020 in the intensive apple orchard of Kursk State Agrarian Academy. The garden was laid in 2016, the planting scheme is $4.0 \times 1.2$ meters, and the varieties include Ligol and Alva on M-26 basement. The studies used a systematic approach to analyze the nutritional regime of seed crops and conduct field experiments with mineral fertilizers and growth stimulants using generally accepted methods. Research design:

1. Control, without foliar dressing, in spring -1 c/ha of ammonium nitrate into the circle around the tree trunk;

2. Variant 1 - foliar dressing with Ikar and Biolchim agents;

3. Variant 2 - foliar dressing with Fitofert Energy and Terra Tarsa agents.

Table 1 shows the integrated foliar dressing schemes for different variants of the experiment.

In our study the foliar dressing systems included special fertilizers and growth stimulators - Ikar, Biolchim, Fitofert and Terra Tarsa. Currently, the products of these companies are one of the most hightech in the nutrition of garden crops.

Each variant included 10 trees in 3 times repetition. The applied complex feeding systems ensured the complete need of plants on the leaf surface with all the necessary feed elements and biostimulators throughout the vegetation period. The studied agrochemicals were introduced by the Oleo-Mac shoulder sprayer and the
Stiel manual shoulder sprayer with a working fluid application rate of 750 liters per 1 ha. Foliar dressing was combined with the introduction of disease and pest protection agents by Singenta and Bayer.

According to the study program, soil samples were selected and analyzed at the beginning (pink bud phase) and at the end of the vegetation period before defoliation. To determine the growth dynamics, a tapemeasure and a 2.5-meter high measuring rack were used. In order to diagnose the content of feed elements in apple plants, the analysis of the content of macroand microelements in apple leaves in the flowering phase and at the beginning of ripening of fruits was carried out. The analysis was carried out by express diagnostics. The yields and quality indicators of the obtained products were determined according to the Program and Methodology for the Variety Study of Fruit, Berry and Walnut Crops [11].

\section{Results and Discussion}

Field experiments on the efficiency of foliar dressing were carried out in garden agropedocenoses represented by dark gray forest soils located within the city of Kursk. They could therefore be characterized as urbanized soils. Table 2 shows the agrochemical indices of the soil site where the studies were carried out.

Table 2. Agrochemical characteristics of urbanized dark gray forest soil, layer 0-40 cm, 2020

Agrochemical indices, beginning of vegetation, May 2020

\begin{tabular}{|l|l|l|l|l|l|l|}
\hline Organic content & $\mathrm{pH}$ & $\begin{array}{l}\mathrm{H}_{\mathrm{r}}, \\
\mathrm{mmol} / 100 \\
\mathrm{~g}\end{array}$ & $\begin{array}{l}\mathrm{S}, \mathrm{mg}- \\
\text { eq/100 g }\end{array}$ & $\begin{array}{l}\mathrm{P}_{2} \mathrm{O}_{5} \\
\text { labile }\end{array}$ & $\begin{array}{l}\mathrm{K}_{2} \mathrm{O} \\
\text { exchange }\end{array}$ & $\begin{array}{l}\mathrm{N} \\
\text { alkaline- } \\
\text { hydra }\end{array}$ \\
\hline 3.3 & 1.77 & 22.4 & 160.0 & 88.0 & 125.0 \\
\hline End of vegetation, September 2020 & 5.4 & 21.5 & 158.3 & 87.7 & 105.5 \\
\hline 3.3 & 5.36 & 1.81 &
\end{tabular}

The data show that the soil has a low content of humus, close to the neutral reaction of the soil environment and the average content of macroelements. Therefore, for intensive orchards cultivated on such soils, full mineral nutrition is the dominant factor ensuring high productivity.

The efficiency of cultivation of intensive apple orchards and their productivity is greatly affected by climatic conditions [3]. These are mainly such indicators as the amount of atmospheric precipitation, the uniformity of precipitation during the vegetation period, optimal temperature and air humidity. Currently, for horticulture, the dominant indicator is the temperature factor, since the lack of precipitation is compensated by modern irrigation systems. The analysis of meteorological data of the Kursk weather station is presented in Table 3.

The presented data show a higher average monthly temperature in 2019 compared to the average long-term data, which favorably affected the growth activity and productivity of apple trees. The subsequent 2020 may be described as abnormal in temperature. In winter months, there were almost no minus temperatures, and the beginning of the growing season was noted in March, which is at least 3 weeks earlier than the average long-term indicators. During the study years, the amount of precipitation corresponded to the average long-term norm, but their distribution was extremely uneven. There is a pattern of minimum precipitation in August and September, which leads to a lack of moisture and it is necessary to monitor the moisture of the topsoil in spring.

The standards for the introduction of fertilizers and growth stimulants were adjusted taking into account the recommendations of the manufacturer, climatic conditions and the features of the growth and development of this variety. 
Table 3. Meteorological conditions during the study years, 2019-2020

\begin{tabular}{|c|c|c|c|c|c|c|}
\hline \multirow[t]{2}{*}{ Month } & \multirow{2}{*}{$\begin{array}{l}\text { Long-term } \\
\text { average } \\
\text { annual } \\
\text { temperature, } \\
{ }^{\circ} \mathrm{C}\end{array}$} & \multicolumn{2}{|c|}{$\begin{array}{ll}\text { Average } & \text { monthly } \\
\text { temperature, }{ }^{\circ} \mathrm{C} & \\
\end{array}$} & \multirow{2}{*}{$\begin{array}{l}\text { Long-term } \\
\text { precipitation } \\
\text { total, mm }\end{array}$} & \multicolumn{2}{|c|}{$\begin{array}{l}\text { Average monthly precipitation } \\
\text { total, } \mathrm{mm}\end{array}$} \\
\hline & & 2019 & 2020 & & 2019 & 2020 \\
\hline January & -10.0 & -6.4 & -1.1 & 34 & 53 & 22.2 \\
\hline February & -8.0 & -2.1 & -1.4 & 33 & 38 & 36.0 \\
\hline March & -2.9 & 1.3 & 4.0 & 32 & 56 & 18.1 \\
\hline April & 6.7 & 9.7 & 6.1 & 35 & 13 & 20.2 \\
\hline May & 13.8 & 16.8 & 11.9 & 50 & 73 & 74.1 \\
\hline June & 17.3 & 21.7 & 20.7 & 59 & 31 & 46.7 \\
\hline July & 18.9 & 18.7 & 21.0 & 71 & 49 & 72.6 \\
\hline August & 18.1 & 19.2 & 18.7 & 64 & 27 & 11.8 \\
\hline September & 12.4 & 14.3 & 16.8 & 44 & 38 & 8 \\
\hline October & 6.4 & 9.5 & 11.1 & 41 & 57 & 27 \\
\hline November & 0.1 & 1.9 & & 41 & 41 & \\
\hline December & -4.3 & 0.2 & & 41 & 30 & \\
\hline Over the year & 5.6 & 9.4 & & 545 & 528 & \\
\hline
\end{tabular}

In applications of foliar dressing, the growth and development of apple trees differed significantly from the control version. This affected the activation of growth processes, the laying of fruit buds, the size of fruits, and ultimately affected the most important indicator - yield. This indicates an improvement in the nutritional regime and an increase in the content of macro-, meso- and micronutrients in apple plants. The use of special fertilizers and growth stimulants according to the experiment variants has a significant impact on the content of macro- and microelements in the leaf plate of the apple tree. Figure 1 shows the results of the agrochemical analysis of the need of apple plants for nutritional elements. The method of rapid diagnostics of the Aquadonis mobile laboratory was used. Functional diagnostic methods are effective because they primarily determine the need of the plant for a particular nutritional element. The need of plants for macro- and microelements may be assessed by controlling the intensity of physiological and biochemical processes, in particular by introducing fertilizers and growth stimulants over the leaf surface. The presented express diagnostic data show that the application of fertilizers and growth stimulants by Ikar and Biolchim in the first variant made it possible to optimize the elemental composition and significantly reduced the need for most macro- and microelements. At the same time, the activity of chloroplasts has significantly increased, which indicates the intensification of biological processes in apple leaves.

RESULTS OF FUNCTIONAL EXPRESS DIAGNOSTICS

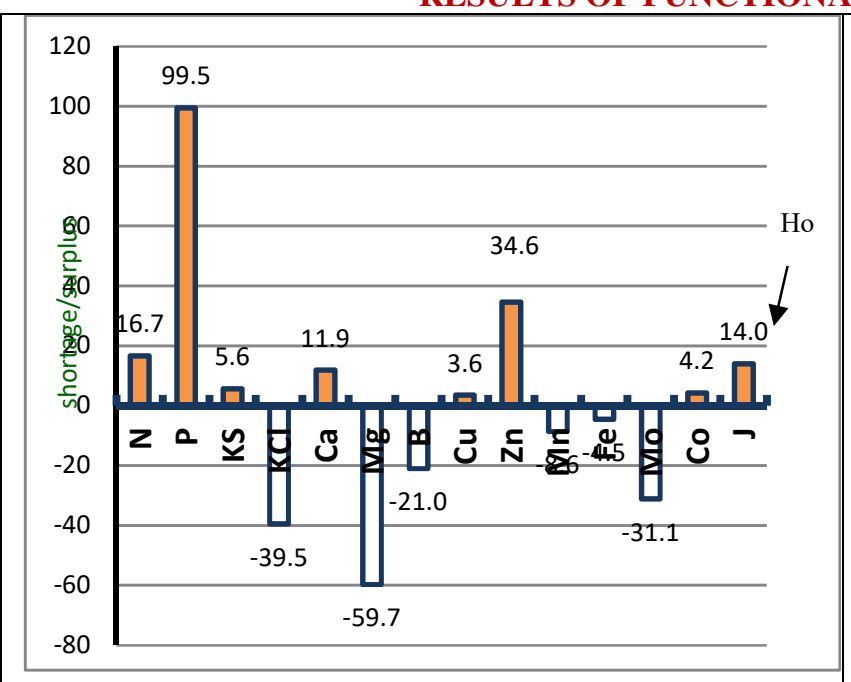

Chloroplast activity, control - $\mathbf{1 3 1}$

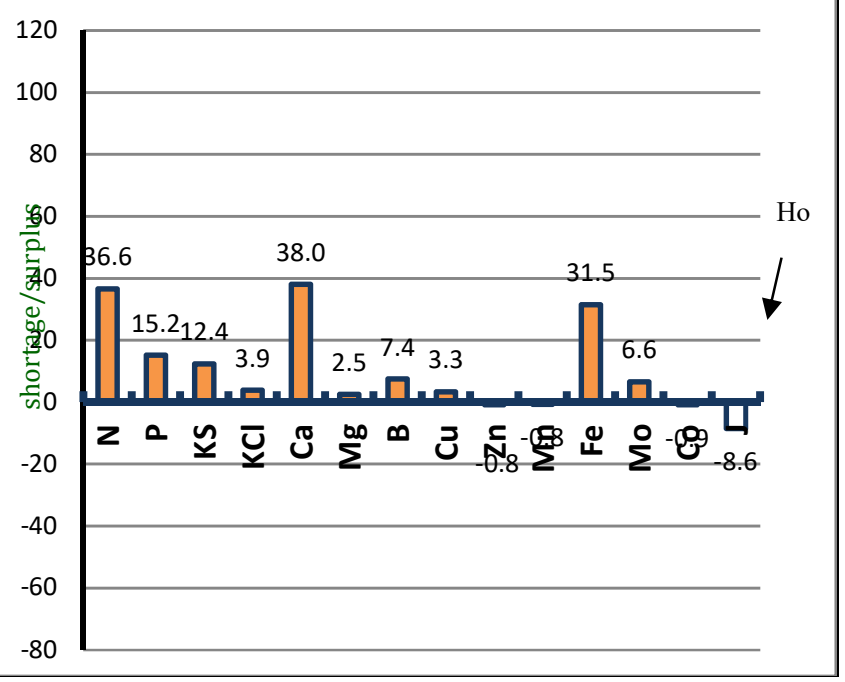

Chloroplast activity, variant 1 - 194

Figure 1. Results of express diagnostics of demand for nutritional elements, Ligol variety

The optimization of elemental composition primarily affected the activation of the growth activity of young apple trees. Our studies identified such indicators as the height and annual growth of the central conductor and the average annual growth of fruit wood. For an intensive support garden a fruit wall at least 3 meters high should be formed for a maximum of 5 years. Therefore, the growth of the central 
conductor is given special attention. As the obtained data (Table 4) show, the use of foliar dressing in the study variants has a significant effect on the growth of the central conductor and its height.

Table 4. Height and annual increase of the central conductor, 2020

\begin{tabular}{|c|c|c|c|c|c|c|c|c|c|c|c|c|}
\hline & \multicolumn{6}{|l|}{ Alva } & \multicolumn{6}{|l|}{ Ligol } \\
\hline \multirow{6}{*}{ 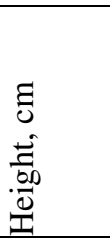 } & \multicolumn{2}{|l|}{ Control } & \multicolumn{2}{|c|}{ Variant 1} & \multicolumn{2}{|c|}{ Variant 2} & \multicolumn{2}{|l|}{ Control } & \multicolumn{2}{|c|}{ Variant 1} & \multicolumn{2}{|c|}{ Variant 2} \\
\hline & $245 / 38$ & $230 / 54$ & $257 / 71$ & $281 / 67$ & $240 / 48$ & $245 / 53$ & $235 / 46$ & $245 / 50$ & $280 / 84$ & $260 / 88$ & $240 / 62$ & $279 / 66$ \\
\hline & $265 / 41$ & $271 / 47$ & $268 / 59$ & $264 / 54$ & $255 / 65$ & $260 / 51$ & $254 / 42$ & $239 / 47$ & $240 / 60$ & $285 / 70$ & $295 / 70$ & $246 / 59$ \\
\hline & $241 / 39$ & $252 / 56$ & $249 / 81$ & $274 / 73$ & $240 / 54$ & $300 / 67$ & $270 / 57$ & $277 / 63$ & $260 / 67$ & $255 / 66$ & $261 / 69$ & $268 / 65$ \\
\hline & $257 / 42$ & $250 / 49$ & $291 / 82$ & $288 / 75$ & $277 / 72$ & $263 / 69$ & $231 / 48$ & $244 / 49$ & $284 / 77$ & $257 / 64$ & $255 / 73$ & $275 / 64$ \\
\hline & $239 / 45$ & $246 / 36$ & $251 / 62$ & $248 / 56$ & $259 / 62$ & $248 / 50$ & $229 / 41$ & $240 / 61$ & $272 / 70$ & $281 / 72$ & $245 / 60$ & $259 / 66$ \\
\hline average & \multicolumn{2}{|c|}{ 249.6/44.7 } & \multicolumn{2}{|c|}{$267.1 / 68.0$} & \multicolumn{2}{|c|}{$258 / 59.1$} & \multicolumn{2}{|c|}{$246.4 / 50.4$} & \multicolumn{2}{|c|}{$267.4 / 71.8$} & \multicolumn{2}{|c|}{$262.3 / 65.4$} \\
\hline
\end{tabular}

Note: variant 1 - Ikar and Biolchim agents; variant 2 - Fitofert Energy and Terra Tarsa agents.

In the control variant of Alva variety the height of the central conductor was on average $249.6 \mathrm{~cm}$ and the gain over the growing season made $44.7 \mathrm{~cm}$. The use of foliar dressing in the first variant increased the height to $267.1 \mathrm{~cm}$. Compared to the control, it increased by $17.5 \mathrm{~cm}$. The annual gain was $68 \mathrm{~cm}$ and compared to the control it increased by $23.3 \mathrm{~cm}$. In the second variant, the height of the central conductor was $258 \mathrm{~cm}$, which is $8.4 \mathrm{~cm}$ higher than the control. The annual gain amounted to 59.1, which exceeds the control by $14.4 \mathrm{~cm}$. In Ligol variety the intensity of annual gain turned out to be higher, which is associated with varietal features. In the control variant the average height was $246.4 \mathrm{~cm}$ and the annual gain was $50.4 \mathrm{~cm}$. In the first variant of foliar dressing the height increased to $267.4 \mathrm{~cm}(+23 \mathrm{~cm}$ to the control) and the annual gain was $71.8 \mathrm{~cm}(+21.4 \mathrm{~cm}$ to the control). In the second variant the height of the trees averaged $262.3 \mathrm{~cm}(+15.9 \mathrm{~cm}$ to the control) and the annual gain made $65.4 \mathrm{~cm}$, which is $15 \mathrm{~cm}$ higher than the control version.

In intensive horticulture, spindle-shaped pruning is used to cultivate apple orchards and therefore it is important to consider the annual growth of side branches, on which most of the fruits are formed and the productivity of such orchards largely depends on this. Table 5 shows the results of practical studies on the growth of fruit wood over the past 2 years. As the data of practical studies indicate, the use of special fertilizers and growth stimulants significantly increased the growth activity of lateral fruit wood on the studied apple tree varieties. At control the growth of the Alva variety was an average $37.0 \mathrm{~cm}$. In the Alva variety in the first variant the average growth increased by 12.5 $\mathrm{cm}$ and amounted to $49.5 \mathrm{~cm}$ compared to the control. In the second variant the growth compared to the control was $8.5 \mathrm{~cm}$ and amounted to $45.9 \mathrm{~cm}$.

Table 5. Growth of lateral fruit wood, 2019-2020

\begin{tabular}{|c|c|c|c|c|c|c|c|c|c|c|c|c|}
\hline & \multicolumn{6}{|c|}{ Alva } & \multicolumn{6}{|c|}{ Ligol } \\
\hline \multirow{6}{*}{$\begin{array}{l}\text { ठี } \\
\text {.ే் }\end{array}$} & \multicolumn{2}{|c|}{ Control } & \multicolumn{2}{|c|}{ Variant 1} & \multicolumn{2}{|c|}{ Variant 2} & \multicolumn{2}{|c|}{ Control } & \multicolumn{2}{|c|}{ Variant 1} & \multicolumn{2}{|c|}{ Variant 2} \\
\hline & 40 & 40 & 55 & 47 & 48 & 56 & 28 & 20 & 32 & 52 & 70 & 37 \\
\hline & 30 & 35 & 70 & 53 & 33 & 60 & 33 & 45 & 62 & 53 & 55 & 38 \\
\hline & 38 & 25 & 48 & 33 & 35 & 40 & 29 & 22 & 60 & 33 & 45 & 48 \\
\hline & 27 & 45 & 54 & 40 & 57 & 58 & 27 & 30 & 38 & 28 & 53 & 43 \\
\hline & 50 & 40 & 55 & 40 & 28 & 44 & 25 & 21 & 77 & 58 & 42 & 29 \\
\hline average & \multicolumn{2}{|c|}{37.0} & \multicolumn{2}{|c|}{49.5} & \multicolumn{2}{|c|}{45.9} & \multicolumn{2}{|c|}{28.0} & \multicolumn{2}{|c|}{49.3} & \multicolumn{2}{|c|}{46.0} \\
\hline
\end{tabular}

Note: variant 1 - Ikar and Biolchim agents; variant 2 - Fitofert Energy and Terra Tarsa agents.

In Ligol variety foliar dressing more activated the growth activity of lateral shoots. In the control version the average gain for 2 years of study was $28.0 \mathrm{~cm}$. The use of foliar dressing in the first variant turned out to be the most effective - an average annual increase of $49.3 \mathrm{~cm}$ compared to the control - plus $21.3 \mathrm{~cm}$. In the second variant the growth of lateral shoots compared to the control variant was $18 \mathrm{~cm}$.
A full balanced nutrition of special fertilizers and growth biostimulators had a significant impact on the productivity of young apple orchards. We determined such as indicators the size of apple fruits (diameter) in $\mathrm{mm}$, the average weight of one apple in grams and the number of apples in 1 tree. Further, yield in t/ha was calculated on the basis of these indicators. Technological indicators for apple varieties are given in Table 6.

Table 6. Technological indicators of apple fruits, 2019-2020

\begin{tabular}{|l|l|l|l|l|l|l|}
\hline \multirow{2}{*}{ Indicators } & Alva & Ligol & \multicolumn{1}{l|}{} \\
\cline { 2 - 7 } & Control & Variant 1 & Control & Variant 1 & Control & Variant 2 \\
\hline Average size of apples, mm & 58.7 & 74.9 & 71.2 & 65.3 & 72.5 & 70.9 \\
\hline Average weight of apples, g & 155.4 & 194.5 & 181.3 & 161.3 & 213.8 & 177.0 \\
\hline Number of apples from one tree & 44.5 & 52.1 & 49.3 & 43.8 & 58.5 & 54.1 \\
\hline
\end{tabular}

Note: variant 1 - Ikar and Biolchim agents; variant 2 - Fitofert Energy and Terra Tarsa agents. 
The application of fertilizers and growth stimulants has a positive effect on the studied parameters. Compared to the control, the average size of apples increased in both variants, both in Alva and Ligol varieties. Under the influence of special fertilizers and growth biostimulators, such indicators as the average weight of one apple and the number of full apples collected from one tree have significantly improved. The average weight of the apple was positively affected by full mineral nutrition, including meso- and microelements. The number of apples from one tree was primarily influenced by growth stimulants and fruit inception. Both uses of foliar dressing compared to the control showed significant efficiency. The effect of foliar dressing in absolute terms turned out to be more significant in the first variant.
Based on the obtained technological indicators of apple fruits, the calculated method obtained a real yield of $\mathrm{t} / \mathrm{ha}$ in each variety for each variant of the studies. The obtained yields are shown in Table 7. As expected, the control version without the use of foliar dressing turned out to be the least productive. In modern horticulture technologies their absence does not provide full nutrition and significantly affects yields. The Alva variety showed a yield of 14.4, and the Ligol variety -15.5 tons/ha. In the foliar dressing system, Ikar and Biolchim obtained the highest yield. In the Alva variety it was 21.1 tons/ha, an increase compared to the control was 6.7 tons/ha. In Ligol variety the highest yield was 25.8 tons/ha, which exceeds the control version by 10.3 tons/ha.

Table 7. Yield by variants, 2019-2020

\begin{tabular}{|l|l|l|l|l|l|l|}
\hline \multirow{2}{*}{ Indicator } & \multicolumn{4}{|l|}{ Alva } & \multicolumn{2}{l|}{ Ligol } \\
\cline { 2 - 7 } & Control & Variant 1 & Variant 2 & Control & Variant 1 & Variant 2 \\
\hline Yield, t/ha & 14.4 & 21.1 & 18.5 & 15.5 & 25.8 & 19.9 \\
\hline
\end{tabular}

Note: variant 1 - Ikar and Biolchim agents; variant 2 - Fitofert Energy and Terra Tarsa agents.

Besides, the system of foliar dressing with special fertilizers and Fitofert Energy and Terra Tarsa biostimulants showed high productivity. In the Alva variety the yield increased to 18.5 tons/ha, which exceeds the control version by 4.1 tons/ha. The Ligol variety showed a high yield and it amounted to 19.9 tons/ha, which is 4.4 tons/ha higher than the variant without foliar dressing.

\section{Conclusion}

1. In modern intensive horticulture technologies the feed system plays a leading role in maximizing the productivity of garden agropedocenoses.

2. The system of foliar dressing with liquid and water-soluble fertilizers and growth biostimulators should become a mandatory technique for complex nutrition systems.

3. When developing a system of foliar dressing, the number of treatments over the growing season, it is necessary to take into account the varietal features of the apple tree, the age of the tree and its growth activity, the planned yield.

4. During the growing season it is necessary to diagnose the content of nutrition elements in apple leaves and, based on the obtained data, to make adjustments to the introduction of preparations.

5. As a result of the use of foliar dressing and biostimulators, biological processes in apple trees are significantly activated, which is reflected in the intensity of growth processes. There is a significant increase in the annual growth of the central conductor and lateral fruit wood compared to the control.

6. The use of special fertilizers and growth biostimulators increases the setting ability of apple fruits, and thus the number of high-quality apples on one tree.
7. Foliar dressing systems had significantly increased the yield of the intensive apple orchard. The system of foliar dressing with Ikar and Biolchim at 19fold introduction increases the yield of varieties from 40 to $66 \%$ compared to the control. The system of foliar dressing with Fitofert Energy and Terra Tarsa at 11 -fold introduction increases yield in varieties on average by $28 \%$.

\section{References}

1. B.S. Gegechkori Innovative technologies in fruit growing: study manual. (Krasnodar: KubSAU, 2014)

2. A.G. Gurin, S.V. Rezvyakova Fruit growing and berry growing of Russia. 57, 42-46, (2019)

3. Yu.V. Trunov, A.I. Kuzin Intensive orchards of the apple tree of the central part of Russia. (Voronezh, 2016)

4. T.G. Fomenko, V.P. Popova, K.V. Belousova 2, 10-17, (2019)

5. L.V. Levshakov, O.A. Smirenin Bulletin of Kursk State Agricultural Academy, 9, 30-38, (2019)

6. A.I. Kuzin Scientific Journal of KubSAU, 130 (06), 958-974, (2017)

7. M. Tagliavini, W. Drahorad, J. Dalla Acta Horticulturae. 594, 9, (2002)

8. A.I. Kuzin, Yu. V. Trunov, N. S. Vyazmikina Fruit growing and berry growing of Russia: Collection of scientific works $\boldsymbol{X X X}, 64-73$, (2012)

9. V. P. Popova, O. V. Yaroshenko, N. N. Sergeeva, T.V. Skhalyakho Gardening and winegrowing, 3, 27-33,(2019) 
10. L.V. Levshakov, N.V. Volobueva, S.G. Yadykin, A.A. Podstrela Bulletin of Kursk State Agricultural Academy. 9, 49-56, (2018)

11. Program and method of class study of fruit, berry and walnut crops (Oryol: VNIISPK. 1999). 